\title{
Madrassa Education System and Political Socialization in Pakistan
}

\author{
*Dr. Fauzia Ghani \\ **Bushra Ghani,
}

\begin{abstract}
:
Madrassa system in Pakistan is providing an alternative mean to education. In Pakistan, different education systems are involved in developing different kinds of social and political beliefs. The most influential of which is madrassa system that is directly affecting the process of political socialization. Being an Islamic state, this system was given much importance after the independence of Pakistan. Islamization policy made religious education more significant. At that time, religious extremism was also increasing in the country. After 9/11 and Enlightenment policy, madrassa system became a controversial system in the world and in Pakistan as well. People now perceive madrassa system as a place of spreading terrorism and extremism. Though, not all the madrassa in Pakistan are involved in extremist militant activities. Most of the madrassas are spreading peace and harmony in the society. This research aims at to analyze the perception of people about madrassa on local and global level. And the most important point is analyzing the impact of madrassa education on its students.But the question arises how does madrassa education is involved in spreading extremism and effecting the social and political beliefs of every individual in the society. The nature of research methodology is
\end{abstract}

\footnotetext{
* Assistant Prof. Political Science Dept, GC University, Lahore

${ }^{* *} \mathrm{Ph}$. D Scholar Lahore College for Women University, Lahore
} 
Madrassa Education System and Political Socialization in Pakistan lhyā' al- 'Ulūm, Volume 21, Issue 1, (Jan-June 2021)

qualitative and research design used is content analysis. In this research, the relationship between madrassa education and political socialization is developed where it is directly and indirectly influencing each other and the public specifically. Though, result shows that people still think of Madrassa system as a negative system but now studies show that there are some good and peace loving madrassa as well. But since the religious political parties are affiliated with madrassas, the social and political beliefs are also shaped according to the policies made by religious leaders and 'Ulmā's showing that religion effects society and politics to a great extent.

Key Words: Madrassa Education System, Political Socialization, Religious Sects, Religious Extremism

\section{Introduction:}

Education is very important for every individual as well as for the development and welfare of society and state. In the case of Pakistan, being a developing country, education is very crucial for every child in Pakistan. In western world, the concept of education system is different and based on science and technology whereas; the Islamic society education system is composed of religious institutes which includes Madāris. Both systems of education were developed to meet the needs of their respective societies. Pakistan is an Islamic state and Madrassa education is given all over the country. This educational system is playing an alternate role for children to get education as it is religious in nature, affordable and in some areas free of costs. More than half of the population of Pakistan is poor and uneducated, and according to them full knowledge of one's religion is what they called being educated. This in return creates the norms and traditions of the society 
alone with politics, which are directly linked with political socialization. Thus, Pakistan have different education systems which are developing different kinds of culture and traditions in society. One of the most prominent systems is that of Madrassa educational system. The relationship and role between Madrassa education and political socialization is thus very essential to identify because education leads to the development of the country in the future. ${ }^{1}$

Political socialization is defined as, "a lifelong process by which people from their ideas about politics and acquire political values." ${ }^{\text {.2 }}$ Political socialization is a continuous and everlasting process. This process helps people make their own opinion about political system and obtaining political values. The agents of political socialization that helps in creating political value and culture includes family, school, educational institutes, peers, religion and media. Though there are some other factors that also influence political socialization. These factors change its shape in every individual's life from childhood to adulthood. ${ }^{3}$ Education plays an important role in any political system; it helps in bringing about political socialization among youth. It also has a great influence in the political system of a country. In Pakistan, political socialization is highly effected by the Madrassa education system. However, this system is criticized on global and also on local level. Religious organizations and Madrassa system in Pakistan has created a setup of politics that even politicians cannot refrain from. They have set their aims for a particular political setup which they are obtaining by spreading and creating political socialization among young students.

Madrassa education system is an institution in the educational system of Pakistan and contributing in providing basic and religious education to 
children. The difference in this education system is that it is providing specific education, in terms of traditions, culture, values, norms and beliefs, it also shapes certain skills of children, and make them socially fit to live and create a peaceful and prosperous society. The purpose of Madrassa in a society is to educate children about Islamic traditions, social and political culture and norms in a Muslim society. Also, it shapes the beliefs of individual and teach them ancient cultural and traditional skills to create a welfare society. Thus, it can be clearly observed that political socialization is highly influenced by Madrassa education. It is because it does not only provide basic education to children but also gives parents satisfaction that their children are getting religious education. But the concept of Madrassa education has been changed and criticized since past few years because they are only teaching religion and are not giving modern scientific and technological education due to which the youth of Pakistan cannot move forward with the world. The social and political beliefs of individuals are also being affected by this system which can be very dangerous for the progress of Pakistan in the future, Though the system has deeply embedded itself in the society that it has become difficult to convince people to stop following traditional extremists education given by Madrassa now a day. Thus, we can say that the role between political socialization and culture of Pakistan is being controlled by religious organizations of the country. ${ }^{4}$ While conducting this research different questions were highlighted such as, what is the role of Madrassa education system and political socialization in society and politics? How influential is this system to the every part of the society and politics? Are Madrassas involved in creating extremists and radical Islamic views in people? What is the Impact of religious education on students? How do people perceive 
Madrassa education system? The objectives of this research was to identify the role of Madrassa in society and politics, to analyze how influential madrassa system is on Pakistani society, To analyze the perception of people about madrassa on local and global scale, also, to examine if the madrassas are involved in spreading extremism and in creating radical Islamic militants. And the most important point is analyzing the factors involved or the impact of madrassa education on its students.

\section{Literature Review}

Madrassa is an Arabic word for Islamic school, literally meaning "a place of religious instructions" ${ }^{25}$. In Pakistan, Madrassas has deep roots in the educational system. Pakistan being a Muslim state cannot entirely ignore the religious teaching. Though, this system is being criticized both globally and locally.

Bhattacharya wrote in his work "Madrasa Education in Pakistan: In the Context of Government Policy"that the amount of its political issues, since the establishment of undisguised activities for the self-interest of political elites have camouflaged it in the name of religion. After the independence, the main aim of ruling class was to declare Pakistan as an "Islamic" Ideological State, not as majority-ruling state i.e. democracy. ${ }^{6}$ On the other hand Anzār says that as Pakistan is an Islamic state, the structure of Madrassa has a great influence in the society. As Islam is the component for being a Muslim state. This is considered one of the biggest reason that Madrassa strongly implies public and religious leaders to create political views and socialization in the same manner. Also, because education is the source from which children learn to create their own opinion, the Madrassa also controls the youth, public decision 
making and even the government to make laws according to Islam. So they can live according to Islamic teachings as it is a code of life. Zaidi claims in his work"Madrassa Education in Pakistan: Controversies, Challenges and Protests"that, in Pakistan, the madrassa education system gives two different views of the public. It can be generalized that half of the population thinks that madrassa is spreading extremism and sectarian violence and other half are of the view that they are only providing basic religious education and are not involved in any extremist activity. The real question is that how madrassa education is involved in creating intolerance in society on social and political values. And how is it affecting the culture and political socialization in Pakistan. One simple answer is, because of being conservative and radical, societal and political values are effected. In short political socialization is being affected. Because youth are the future asset of a country and the agents of political socialization show that young students are on front scale to be effected by this system. Not only students but religious elites are also taking part in controlling the minds of majority of population in Pakistan. ${ }^{7}$

Sajjād argues in his article "Madrasas in Pakistan: thinking beyond terrorism-based reforms" that Madrassa are considered very significant for every society because of four major reasons. These are "education policies, Islamization drives, recruitment of clergy and social impact" in society. According to him, these four aspects are very essential to be made part of educational policies so that the significance of Islamic teaching in the educational system should be observed. The existing literature shows that about only $40 \%$ of the total $70 \%$ population of children from 5 to 19 years of age are going to school said by Das, J., Pandey, P., \& Zajonc, T. He argues that the rest are going to Madrassa for education and some of the population 
Madrassa Education System and Political Socialization in Pakistan lhyā' al- 'Ulūm, Volume 21, Issue 1, (Jan-June 2021)

other than the $40 \%$ is doing nothing. The reason why children below 5 years of age and the rest $30 \%$ are going to Madrassa is because they are easily affordable, and public and private sector schools are not established in rural areas. Private sector is costly and their curriculum also differs from public sector and gives little knowledge about Islamic teachings. This makes Madrassa filling the gaps for poor children to get education. In a society where madrassa is easily approachable, the majority will definitely spend their children to this system. He also claims that our society do not consider Madrassa system as a very influential system and most of people do not even recognize it. We don't need to think of madrassa as a bad system because some of the Madrassa do promote good means of education. That is why the opinion of people also varies and are extreme at both ends i.e. one with liberal thoughts and other with extremist thoughts that directly affects the process of political socialization. ${ }^{8}$

Manzar Abbās Zaidi explains in his work that Madrassa education is wrongly perceived in Pakistan as spreading radical Islamist ideologies, creating terrorist and that they are directly linked with terrorist organizations. Both the extremist organizations are portraying this in a way that people in society are forced to believe about the negative side of Madrassa. To some extent, Madrassa students are aggressive and rigid about Islamic policies and its practice in the society. If we see the relation between political socialization and madrassa education, than religious leaders who are radical are exploiting the agents of political socialization and are using it against liberal or secular school of Pakistani society, in creating violence. This leads to security threats (sectarian violence, blasphemy cases etc.) on both social and political ground. ${ }^{9}$ Ahmed in his work "The Madrassa Myth: in Pakistan, Public Schools 
Madrassa Education System and Political Socialization in Pakistan lhyā' al- 'Ulūm, Volume 21, Issue 1, (Jan-June 2021)

may be the Problem" expresses different views from other researchers in her report. She claims that there are some madrassas in Pakistan that are providing righteous religious and spiritual education. The outcome of these madrassa students are also seen to be positive and are not extremists or rigid on religion. These madrassa only make students learn Qur'ān orally and give basic religious education. According to the teachers or 'Ulmā of these Madrassas, they say that they do not go deep in religious and spiritual studies, so that they won't get involved in any negative activity and perceived wrongly in the society. But the point is that everyone Madrassa student perceive different views from religion as they experienced or make opinions based on what they hear and think when they grow-up. ${ }^{10}$ Mohammad Amir 's work "Mapping the Madrasa Mindset: Political Attitudes of Pakistani" also explains same views. He says that Madrassa have gained importance in Pakistan as many societies especially rural areas still supports this system as a culture of their society. It was then recommended for Madrassa that they should take part in societal activities with private and public sector schools so that they norm (of madrassas) could continue for social and political benefit. For this purpose, media can be very significant in promoting the positive and rightful education of Madrassa so that people could also see another true side of Madrassa system as well and so the distinguishing factors between madrassa student and other students could be ignored or eliminated. ${ }^{11}$

Although, we still cannot infer the point that all madrassa systems, its education and functioning is based on righteous activities because more religious leaders and students are observed to be aggressive and involved in violent activities while other students are not much violent. Thus, being majority in population, the socialization process and its effects on society is 
only creating biasness, hatred and people favoring secular beliefs more than Islamic belief while the latter is the actual ideology of Pakistan.

\section{Madrassa Education and Political Socialization: Findings}

Religious education is necessary in any Islamic state. Madrassa education system in Pakistan is therefore, a mandatory education system in the country. In spite of facing all the challenges and controversies from local and global scale, this educational system plays a significant role in the society. The importance of Madrassa as a social institution cannot be ignored or avoided by considering that it is the source of extremism in the country. Because no one really knows if this is the work of madrassa or not. Studying the role of political socialization and madrassa education system, we can say the madrassa have direct influence over the societal and political mindset of every person. This influence is either intentional or unintentional. This also depends on the mindset of an individual that how they perceive things being taught in madrassa and what they learn from society and media. The factors that effects political socialization linking with madrassa system are described below:

\section{1) Family:}

Family is the first learning place of a child and one of the most influential one. Family builds the minds of children before they go to school. In Pakistan, due to class difference, the thinking and behavior of children also varies from class to class. Majority of the people lives in rural areas, are poor and uneducated. This is main reason why most of the children end up in madrassa and do not go for further studies. One reason because madrassa are affordable and provides a place for eat and sleep to the children who live far away. These 
kind of children have no or very little exposure to urban areas and even technology. Such children are highly effected by madrassa teaching and they become rigid and intolerant towards others views on religion. The family setup of a rural family is also conservative and traditional, therefore they do not like to change any of their culture and norms. It is also because their parents' focuses only on madrassa education and they are not aware of modern world, science and technology. The difference can be seen from here, children living in urban areas goes to public or private sector schools and they parents are also educated. Though they do get a little religious education but it is not compulsory. They are more open-minded and have flexibility in their views. The family setup of an urban area is more liberal and they believe in holding personal opinion. This results in different kind of social and political behavior and values adopted by the children of rural areas and urban areas. The rural areas students are more rigid and have conservative views about different societal and political matters. Even if they go for higher education, the mindset that develops in a child never changes. Whereas, urban areas students have more flexible, diverse and liberal views about society and politics. Rural area students also lack confidence and do not hold any personal opinion, they believe that their Ulmā's or Imams have taught them right whereas this is not the case in urban areas.

But exceptions do exist, in the current time period, some madrassas have modified their curriculum, including basic science and technology studies as well. Other than that in the recent timeframe, rural area parents are sending their children for further education. And this is also not true that only rural areas students go to madrassa, parents in urban areas belonging to upper and middle class also send their children to madrassa for making them Hāfiz or 
Hāfiza, but because the family setup of urban areas is a little liberal therefore the minds of the children are not affected by it.

\section{2) Education/ Schools:}

Educational institutes are the secondary factor in influencing political socialization of a society after family. A child's spiritual teaching starts from schools. Majority of the people in Pakistan are poor and have no other option than sending them to madrassas. Though, children in urban areas go to public and private sector schools. But now parents in urban areas prefer sending their children to private institutes than public schools and madrassa. Because they know that the personality of a child is built in schools. And people perceive about madrassas differently that either they spread extremism or they promote peace. Madrassa students who take higher educations in madrassa become 'Ulmā's or Imams in the society, whereas, children going to private schools aim differently. Few madrassa students aim in going to any different field other than being 'Ulmā or Imams. Taking a look at the curriculum and teaching methods of madrassa student, one could see that it is more biased and supports any one sect. This biasness and hate literature has resulted an increase in Sectarian violence, Blasphemy cases and spread of hatred by hate speech for other sects. As there are 5 different Muslim sects in the country and 5 different kinds of Madrassa educational system under one name, therefore the risk of rise in sectarian conflicts could be predicted. But not all madrassa curriculum is based on biasness and conservative views. Some madrassa are actually promoting peace and harmony though their educational system. But people especially students would not agree. The reason is that when seminars or debates occur between schools, the madrassa students show no tolerance and harmony towards the other person who do not share same views. This 
Madrassa Education System and Political Socialization in Pakistan lhyā' al- 'Ulūm, Volume 21, Issue 1, (Jan-June 2021)

results in rigid conservative environment in the society. Due to their biased views and intolerance, the religious leaders and such madrassa students creates a culture of society and politics more rigid and harsh to follow. Other than this, when a child continuously studies such narrow-minded views, they become more rigid and extreme which can be resulted in radical or extremist students coming from madrassa. Madrassa student believe in traditional norms and culture and do not like liberal views which has resulted in such extremist behavior in the society. This behavior is also effecting politics, because religious political leader also demands the same old traditional rules and culture and anyone who go against such tradition, they consider them as nonMuslims. Due to which conflicts rise in society and it is a serious threat to the current Pakistani society and for its social and political values and beliefs of a country.

\section{3) Peer Group:}

Peers groups are very influential in the process of political socialization. Relating peer groups with madrassa education shows that in society, people have different perspective for madrassa education. Some people are of the opinion that madrassa education is the source of spreading extremism and terrorist activities, while some are of the opinion that they spread peace and harmony in the society. Because of the difference of opinion of people in every society, youth perceive madrassa education in the same way. In reality, youth develops their opinions based on what the society says. Students of Madrassa and private sector schools hold diversity in thoughts and opinion but peer groups play more significant role in shaping the mindset of youth and children. Because in school going age, children spend more time with their 
friends and peer groups effects mostly during that age. When peer belonging to same school system or society interact with each other, they learn similar things and are more adaptive to same kind of environment, thoughts and behavior. But when peer belonging to different communities interact, that's when a child/youth develops their behavior and attitude towards society. As the study shows that madrassa are more rigid and private sector students are not, when both sectors' students interact, the minds of those students will be influenced by one another. This results in youth developing different social and political behavior of the society. This simply shows that the society is also divided into different segments، one that take influence from madrassa student and become rigid and intolerant. The other segment, in which the madrassa student will be influenced by the other schools students and will adapt flexibility and liberal views in religion and worldly affairs and the last segment, is the mixture of both the segment, with moderate views about religion and worldly affairs. But parents easily get influenced by the peer groups of society, which are of the opinion that madrassa going children do not any bright future. Parents (affected by society) thinks of a better future for their children and they can easily see this future by sending their children to private or public sector institutes. Because there is no successful, modern technology literate studies in madrassa education. But this is not true, there are many students who take madrassa education during their school going age and continue further studies in public and private sector for the better future. The problem is not that madrassa education system is wrong. The problem lies within the beliefs and opinion of people and what they perceive from society. 


\section{4) Media:}

Media plays a significant role in shaping people's public opinion, social and political behavior of every individual in a society. Since, now young generation and even adults have more exposure to mass media. Young people have more focus on social media which shapes their mind in whatever way they want. Looking at global and local level, madrassa education is being criticized all over the world for producing terrorist and Islamic militants. When an innocent mind see the news of terrorist linked with religion and madrassa, they eventually try to avoid and develop negative opinion about both, religion and madrassa. Such people will likely to adopt secular or to some great extent would become Atheist. Though the poor would never adapt such beliefs because they do not have enough exposure and they are mostly madrassa graduates. They would likely to adapt negativity from news channels and such programs who target Islam as an extremist religion and cause of terrorism. This is happening even in Pakistan. Media should give importance to madrassa system and should talk about Islam as a religion spreading peace and harmony. Instead of creating differences in madrassa education and private sector schools, media should give significance to religious education in Pakistan society and should promote positive image of madrassa in society. So people could also see the hidden face of madrassa whose sole purpose is about love, peace and harmony for protecting political culture rather than separating and creating hatred in the society.

\section{5) Religion:}

Religion and madrassa are closely tied with each other and when it comes to effecting political socialization. Religious beliefs influence political and 
social opinion of public in society. Madrassa education teaches religious education to children. The opinion of madrassa students are also based on religion. They have rigid views and are likely to be intolerant. But this is not true in every matter. Most madrassa students are peace lover and patience when it comes to religion. Though, public and private sector students are more liberal in religious beliefs. But exceptions are always there, some public and private sector students have rigid and radical views about religion as well. Though, the number of such students is a little less. The thing is whenever it comes to religion; every Muslim gets rigid and tries to prove their point which makes a rigid social and political attitude in a Muslim country.

\section{5) Political Parties:}

In Pakistan, religious political parties have direct influence in the process of political socialization and in supporting religious education. Majority of the madrassa in Pakistan are linked with religious political parties. These parties believe that religious education is very essential because intervention of religion in politics is obligatory. In simple words, politics cannot work alone. Religion should be alongside politics in every matters and in policy making. Madrassa also favors this statement, protect their interests and educate students in the same manner. Religious schools such as, Dār-ul-'Ulūm and Dār-e-Arqam have more religious-political goals than any madrassa, though, some madrassas are also involved in politics. Jamāt-e-Islāmī, Jami'atUlamā-eIslam, all have their own madrassa to support their political goals. Though, madrassa involvement in politics distracts students from education which lead towards more rigid mindset of students resulting in extremism, intolerance, sectarianism and other violent activities. 


\section{Results}

Madrassa in Pakistan are very important and cannot be banned permanently. Thus, it has become important to examine the problems and challenges that Madrassa faces so they could be bought up to other systems of education in the country. In simple words to tackle extremism, teaching method of Madrassa would meet the criteria of public and private sector educational institutes' i.e. unbiased and neutral teaching method. And also by adding scientific and technological education to make them reformed and modernized. Being an Islamic country, Madrassa system is an essential part of the Pakistani culture; therefore we cannot avoid or ban Madrassa from the society. Madrassas will keep on filling that aperture and accordingly changes must be made for its cooperation into the standard of society, instead of having harsh control over them. In the society of Pakistan, Madrassa institutions are also linked with other institutions of the society as well; Such as "mosques" and other religious sectors of the society. Mosques are regarded as a great social institution for social and welfare work as well as holy places for offering prayers. Majority of the students who graduate from Madrassas become "Imam" in the Mosques. Most parents have no option other than sending their children to Madrassas. This effects society in two different ways; First, the madrassa students either become Ulmās, Imams or those ministers who run religious organization, some students either open their own religious institutes and some keep working in Madrassas and other Islamic organizations. And the other one is that it leaves radical conventional influence over the society. Before independence, Muslims fought for their own separate Islamic state where they could practice Islam, Though, Pakistan's state religion Islam which was strengthened by General Zia-ul-Haq 
during his regime. Political socialization and culture also embedded deeply in Islamic practices. Ulmā and religious leaders had great control over the society and the government. But after 9/11 and General Pervaiz Musharraf's Enlightenment policy, Madrassa system became controversial in the world as well as in Pakistan. Since the Tālibāns have gone against Pakistan, the Madrassa have also been divided in different categories. Every Madrassa is based on sects which are creating conflicts with other sects of Madrassas. The process of socialization has also been affected by this division of Madrassa. It has become difficult to identify which Madrassa is promoting extremism and which one is not. The curriculum of Madrassa schools also includes biased and extremist books. Sunni Madrassa students are aggressively against the Shia school of thought and its Madrassa. The result of this is the increase in Sectarian violence in the country. Not only Sunni and Shia have sectarian conflict, the Deobandis, Brēvlies and Ahle-Hadīth are also against each other. And each sect target other sects claiming that they are following right path of the religion and the other is not. Even today, people of every society are against each other on the basis of sect. This is resulting in more cases of Blasphemy acts. The recent murder of, Mashal Khan at Abdul Walī Khan University, clearly shows how even young students are becoming violent and aggressive, and killing their own fellows. They killed the boy accusing him of committing Blasphemy (which in reality is not true). The rigid and biased teaching of Madrassa is creating a culture of extremism, hatred among each other and intolerance. In short, Madrassa education system is producing a rigid conservative Islamic culture in the society making people afraid of such a strict religious system. 
One can easily find difference between a Madrassa student and student of public or private institutes. The mindset of public and especially private institutes is more liberal, tolerant and rational. Whereas, the students of madrassas are conservative, intolerant and does not prefer being rational. In Pakistan, the influence of Madrassa also differs in urban and rural areas. In rural areas, religious leaders are more influential. People in rural areas are mostly poor and do not have enough money to send their children to school, that is why most people send their children to Madrassas so that they can get basic education. This results in more rigid social and political values in rural areas. If Madrassa students from these areas are sent to urban areas or any other village for seminars or talks i.e. debates, they show more aggression in the behavior and are rigid over their opinions and do not even tolerate to listen to what the other had to say. Whereas in urban areas, private and public sector students are flexible and have patience in listening to others opinions. If we look on broader scale, a religious political leader and other political leaders will have a wide range of differences in ruling.

In Pakistan, everyone has different perspective on madrassas. Some believe that Madrassas education is all about "Jihad", having no concern with educating students about the right and wrong. Instead are involved in spreading 'political indoctrination', a breeding place for terrorist and from where rigid and aggressive religious beliefs are formed, all of these factors are a big threat to every country of the world ${ }^{12}$. There is another school of thought who believes that Madrassa is a righteous institution, spreading peace and are not involved in any such activities. The basic concern of this kind of Madrassa is to teach students moral, social and political values. But in Pakistan people perceive Madrassa in the negative manner. Though both positive and negative 
Madrassas exist in the society and they share almost equal number but since the image of Madrassa have been negative worldwide, therefore on local level, people perceive it in a negative manner. The biggest misconception created by West and even Pakistani is that only poor children go to Madrassas. In rural areas, parents mostly send their children to Madrassa, especially girls are only sent for Madrassa education so that they could have basic Islamic education. According to them they do not need any further education or also because some parents wants to make their daughters Hāfizas (the one who memorizes Qur'ān). Though that is not true that only poor parents send their children to Madrassa, middle class and upper class families also send their children to Madrassa as well so that they may also know about their religion. Not only girls are sent there by both these class but young boys are also sent there. The main purpose of sending young boys to Madrassa is that they could memorize Qur'ān. If we look at any society, the number of young boys belonging to poor families will be equal or a little less to the number of young boys belonging to middle class families. Another misconception is that Madrassas are poor institutes, and do not have good class rooms for students where they study. The truth is, most Madrassas are wealthy enough to have different class rooms of boys and girls. They also have proper rooms and mess (eating place) where young boys and girls can live if they are from far of areas. Some madrassas also afford vans for giving pick and drop service to students. All of this economical support comes from the "public" as already mentioned by Ali (2006) in her report. ${ }^{13}$ But there are always some exceptions. Few madrassa in rural and urban areas are actually poor and depends on the money of Charity and Zakat. The Charity and Zakat is also given by elite class of the society. Some political elites greatly support this system. Students from 
Madrassa Education System and Political Socialization in Pakistan lhyyā' al-'Ulūm, Volume 21, Issue 1, (Jan-June 2021)

Madrassas offer free education to children. These students when graduate open their own their own Madrassas (especially boys) and work for the welfare of society as well. Some gets involves in societal cultures and norms practices e.g. for having Mehfil-e-Milād at different places in society. For Nikkāh ceremony, spiritual and religious talks, and for offering pray at funerals, etc. Young girls on the other hand, also open institutes or work in religious organization and give Daras to young females of society.

\section{Conclusion}

Madrassa system is a conventional system of education in Pakistan. Being an Islamic state, madrassa education gives satisfaction to parents that their children are learning about their religion. But since 9/11, the role and education system of madrassa have been criticized locally and globally. The Islamization policy of Zia-ul-Haq and Enlightenment moderation policy by Musharaf has led to more controversies and challenges for madrassa system in Pakistani society.

The role of madrassa education in political socialization shows that political beliefs become more rigid and intolerant in madrassa students. Madrassa who are associated with political activities and religious-political parties tend to have radical views and mindset of students which lead towards extremism and violent activities. The role of madrassa in the process of political socialization has different effects in rural and urban areas. Because in rural areas have little exposure to the world of technology and science, therefore the mindset of those areas are rigid and they are narrow-minded about religion, country and the world. In urban areas, even if parents send their children to madrassa, they give them higher education in public and private sector schools. Such students 
going to different schools and having more exposure to the world are more

liberal and have open-minded views. Most importantly, Madrassa who are linked with religious political parties believe that religion and politics should work side by side. Madrassa students think that it is obligatory for them to take part in politics. But this has resulted in violent extremist activities in politics and society. Thus, madrassa education system has been deeply rooted, itself, with politics and political socialization in Pakistan.

\section{References:}

${ }^{1}$ Zaidi, S. M. Madrassa Education in Pakistan: Controversies, Challenges and Protests. Center for International and Strategic Analysis. (2013)

${ }^{2}$ Cliffs,Political Socialization.2016. Retrieved April 20, 2017, from Cliffsnotes.com: https://www.cliffsnotes.com/study-guides/american-government/publicopinion/political-socialization

${ }^{3}$ Kataria, R. J. Political Socialization in Pakistan: A Study of Political Efficacy of the Students of Madrassa. South Asian Studies, 32(2), (2017). 363-398.

${ }^{4}$.Ibid.,

${ }^{5}$ Encyclopedia. "Madrassa". Retrieved from encyclopedia.com: https://www.encyclopedia.com/religion/encyclopedias-almanacs-transcripts-andmaps/madrasa , (2018, 04 07).

${ }^{6}$ Bhattacharya, Sanchita. "Madrasa Education in Pakistan: In the Context of Government Policy." Global Eductaion Magazine. 2015.

${ }^{7}$ Zaidi, Syed Manzar Abbas. Madrassa Education in Pakistan: Controversies, Challenges and Protests. Center for International and Strategic Analysis. 2013.

${ }^{8}$ Sajjad, Mohammad Waqas. Madrasas in Pakistan: thinking beyond terrorism-based reforms.Institute of Strategic StudiesIslamabad. 2009.

${ }^{9}$ Ibid.,

${ }^{10}$ Ahmed, Beenish. The Madrassa Myth: in Pakistan, Public Schools may be the Problem. The PRI's The World. 2013.

${ }^{11}$ Rana, Mohammad Amir. "Mapping the Madrasa Mindset: Political Attitudes of Pakistani." Conflict and Peace Studies. 2(1) 2009: 1-13

${ }^{12}$ Butt, T. M.. Social and Political Role of Madrassa: Perspectives of Religious Leaders in Pakistan. South Asian Studies 27(2),2012, 387-407.

${ }^{13}$ Ali, Farhana. "Inside Pakistan's Madrassas." Terrorism Focus (3)2006: 4-5. Retrived From: http://newlearningonline.com/new-learning/chapter-8/inside-pakistans-madrasas. 